\title{
TOWARDS A TYPOLOGY OF DIMENSIONS OF THE CONTINUITY AND DISCONTINUITY OF LAW: THE Perspective of Polish Private LaW AfTer the 1989 TRANSFORMATION
}

\author{
RAFAL MAŃKO*
}

\section{INTRODUCTION}

The issue of the continuity and discontinuity of legal culture, especially following a radical socio-economic and political transformation, is gaining relevance for legal scholars, especially all those working at the interstices of the sociology of law, the history of law and legal theory. ${ }^{1}$ Doubtlessly, this growing interest in the continuity of legal culture is due to the concrete historical conjecture: almost three decades ago, the countries of Central and Eastern Europe, ${ }^{2}$ as well as Eurasia, ${ }^{3}$ experienced an

DOI: $10.1515 /$ wrlae-2018-0007

${ }^{*} \mathrm{PhD}$ in law (University of Amsterdam), Master of laws (University of Warsaw); External Fellow at the Centre for the Study of European Contract Law (University of Amsterdam) and Associated Researcher, Centre for Legal Education and Social Theory, University of Wrocław. The views expressed in this paper are strictly personal and do not represent the official position of any institution or organisation. The present paper was prepared as part of the National Research Centre (Narodowe Centrum Nauki, Poland), research project no. UMO-2016/21/B/HS5/03221. The article reflects the state of Polish legislation as of 20 January 2018.

${ }^{1}$ See e.g. Tomasz Giaro, 'Some Prejudices about the Legal Tradition of Eastern Europe' in Bronisław Sitek (ed), Comparative Law in Eastern and Central Europe (Cambridge Scholars Publishing 2013) 26ff.

${ }^{2}$ On the notion of Central and Eastern Europe, see Rafał Mańko, Martin Škop and Markéta Štěpáníková, 'Carving out Central Europe as a Space of Legal Culture: A Way Out of Peripherality?' (2016) 6.2 Wroclaw Review of Law, Administration and Economics. See also Katalin Kelemen \& Balazs Fekete, 'How Should the Legal Systems of Eastern Europe Be Classified Today?' in Attila Badó et al (eds), International Conference for the 10th Anniversary of the Institute of Comparative Law of the University of Szeged (Universitätsverlag Potsdam 2014); Katalin Kelemen, 'I sistemi giuridici dell'Europa orientale' in Vittoria Barsotti \& Vincenzo Varano (eds), La tradizione giuridica occidentale: Testo e materiali per un confronto civil law common law (5th ed. Giapichelli 2014).

${ }^{3}$ Understood here as lands of the former Russian Empire and later the USSR. On Eurasia as a legal notion, as developed in the legal theory of Eurasian thinkers, see recently Булат Венерьевич Назмутдинов, Законь из-за границьл: Политико-правовые аспекты 
unprecedented political, economic and social transformation, abandoning the project of state socialism and moving towards capitalism and liberaldemocratic constitutionalism. The shift was radical, although it followed, in reverse, the path of development taken by the same countries four to seven decades earlier, in the aftermath of the October Revolution and the subsequent development and expansion of state socialism as a distinct system of political organisation, with an impact also upon the legal system. Following such radical political, economic and social changes, legal researchers have been posing the legitimate question regarding the influence of such changes upon legal culture, understood as the totality of the juridical phenomenon in a concrete historical period. ${ }^{4}$

It is not difficult to note that, just like after 1917 in Russia, ${ }^{5}$ after 1989 in Central Europe, the discontinuity of legal culture was not total. Continuity can be observed in the reuse of earlier legal texts, in the continuity of interpretive practices, in the organisation of legal professions, and the like. ${ }^{6}$ The analysis and description of various instances of continuity and discontinuity of legal culture begs the question of the prevalence of one over the other, and the significance of continuity in the face of radical change. However, it seems that the discussion on this issue still lacks a sufficient conceptual structuring, which creates the risk of an incomparability of claims concerning continuity vs. discontinuity in different legal cultures, different epochs and different areas of the law. It is precisely in this context that the present paper aims at offering a proposed narrative structure for the debate on the continuity and discontinuity of law, by putting forward a tentative set of dimensions of such continuity, intended as theoretical categories which can be utilized as ideal types (Idealtypen) rather than a clear-cut classification. The added value of introducing a typology of the forms of continuity stems from the fact that it can help organise scientific discourse, especially for the purposes of comparing the relative degree of continuity and discontinuity in various areas of the law (constitutional, administrative, criminal civil, etc.) and in various countries. Without such a coherent and common framework, the discussions of a comparative nature risk becoming unsustainable, and scholars from different countries

классического евразийства (Норма 2017). Specifically on the borders of Eurasia according to classical Eurasianists see pp. 139ff.

${ }^{4}$ Thereby including, especially, legal texts, legal practices, values, self-conciousness of the legal community, and the like.

${ }^{5}$ See e.g. Tatiana Borisova, 'The Legitimacy of the Bolshevik Order, 1917-1918: Language Usage in Revolutionary Russian Law' (2012) 37.4 Review of Central and East European Law 395; Tatiana Borisova and Jukka Siro, 'Law between Revolution and Tradition: Russian and Finnish Revolutionary Legal Acts, 1917-1918' (2014) 3 Comparative Legal History 84; Tatiana Borisova, 'The Institutional Resilience of Russian Law Through 19051917’ (2017) 5.4 Russian Law Journal 108.

6 Rafał Mańko, 'Transformacja ustrojowa a ciągłość instytucji prawnych - uwagi teoretyczne' (2016) 16.2 Zeszyty Prawnicze 5; idem, 'Demons of the Past? Legal Survivals of the Socialist Legal Tradition in Contemporary Polish Private Law' in Rafał Mańko, Cosmin Cercel and Adam Sulikowski (eds), Law and Critique in Central Europe: Questioning the Past, Resisting the Present (Counterpress 2016). On the continuity in the sphere of legal mentality and judicial methodology, see Alan Uzelac, 'Survival of the Third Legal Tradition?' (2010) 49 Supreme Court Law Review 377; Zdeněk Kühn, The Judiciary in Central and Eastern Europe: Mechanical Jurisprudence in Transformation? (Martinus Nijhoff 2011). 
researching different areas of the law may end up 'talking over each others heads' when speaking of the continuity of discontinuity of legal culture.

Therefore, the paper has above all a methodological-theoretical character; it resorts to conceptual analysis as its main tool, supplemented by historical and comparative analysis. The conceptual analysis of legal continuity in this paper can be described as 'phenomenological' in the sense used by Al'eksandr Koževnikov (Kojève), i.e. it is based on analysing the ideal type and its essence, which is then subject to verification on the basis of various cases of its realization. ${ }^{7}$ In casu, the phenomenon of continuity of law is studied on the basis of the culture of Polish private law after 1989; the findings are then generalised to produce categories which can be used for other areas of the law, other legal systems, and other historical periods. Koževnikov rightly opposed the phenomenological approach from metaphysical and ontological analysis, pointing out, however, that a phenomenological description is 'far from being perfect' ${ }^{8}$. The phenomonelogical character of the analysis rests in casu in its attempt to identify the basic and irreducible elements of legal continuity, i.e. those which cannot be conceptualised in terms of a different form of continuity, in the light of a concrete juridical experience. ${ }^{9}$ Indeed, the dimensions of continuity of legal culture put forward in this paper can be seen as a generalisation of the experience of Polish legal culture following the demise of state socialism. The approach used in this paper rests upon identifying the known phenomena of continuity and reducing them to fundamental dimensions which cannot be reduced to any others.

In line with this methodological approach, the references to Polish private law after 1989 and its continuity/discontinuity, ocurring in this paper, are not intended to be a fully-fledged historical, comparative or dogmatic analysis, but rather an illustration of the methods put forward on the basis of a purely theoretical analysis, developed against the background of an existing body of earlier research. ${ }^{10}$ This is in line with the assumption that the methodological tools put forward in the paper are intended for universal application. Therefore, they are neither limited by subject-matter (e.g. private law, public law, criminal law), nor time (post-1989) nor geographic location (Poland). In fact, they can be used for any period and any legal field. However, they will come in particularily handy in analysing legal continuity following a deep political and socio-economic

\footnotetext{
7 Alexandre Kojève [properly: Al'eksandr Koževnikov], Outline of a Phenomenology of Right [1943] (Rowman and Littlefield, 2007) 30-31.

8 ibid 30.

${ }^{9}$ It appears that in philosophy, phenomenology is understood as the study of experience (see e.g. David Woodruff Smith, 'Phenomenology' in Edward N Zalta (ed.) The Stanford Encyclopedia of Philosophy (Winter 2016 Edition), available online at: https://plato.stanford.edu/archives/win2016/entries/phenomenology/ (last accassed: 29.11.2017). Per analogiam, therefore, the phenomenological approach to legal culture can be understood as as the study of the juridical experience.

10 See in particular my earlier publications on the continuity of socialist legal culture in Poland after 1989: Mańko, 'Transformacja' (n 6); Mańko, 'Demons' (n 6); Uzelac (n 6); Kühn (n 6).
} 
transformation, such as the one experienced by Poland and other Central and Eastern European countries following the demise of Communism.

Finally, it should be emphasised that the dimensions of continuity identified in the paper should be treated as ideal types and not as a form of classification. Hence, the borders between the types need not always be clear and overlaps are possible. Furthermore, the types of dimensions identified in the present paper are not exhaustive; other dimensions, within which the interplay between continuity and discontinuity of legal culture can be studied could also be identified, especially with regard to the functioning of the legal academia (both in its research and education aspects). As a final caveat it should be emphasised that the notions of 'continuity' and 'discontinuity' of legal culture should be understood as an axis with infinitely many shades of gray between the ideal types of 'absolute continuity' and 'absolute discontinuity', which most probably do not exist in the empirical world, ${ }^{11}$ but are only a priori categories allowing us to order concrete phenomena of continuity and change along an imaginary scale.

The paper focuses on the continuity and discontinuity of law understood as one of the components of legal culture ${ }^{12}$; it does not encompass the continuity and discontinuity of the entire legal culture. Therefore, such spheres of legal culture, built around and upon the law, such as legal education (organisation of law faculties and professional apprenticeships, teaching methods and curricula), legal scholarship (organisation of legal research, research methods and topics, methods of academic reasoning and interpretation of the law by the doctrine) and adjudication (structure of the courts, selection of judges, judicial training, judicial methods of work, especially with regard to methods of operative interpretation and application of the law by courts and tribunals) are outside the scope of the present paper. It focuses only upon law (in the positivist sense - a set of binding rules, proclaimed and sustained by the authorities) treated in the context of legal culture (i.e. as a cultural phenomenon).

\footnotetext{
11 The closest that one gets, within our Europocentric legal experience, to absolute continuity would be the traditionalist English Common Law (which, of course, nonetheless evolves with every new preecedent which is a source of law), and to absolute discontinuity - in the case of the Bolshevik abolition of imperial Russian law with one blow in 1917. But even in the latter example certain elements of continuity - even if hidden and non-obvious - still can be found. See e.g. Borisova, 'Legitimacy' (n 5); Borisova and Siro (n 5); Borisova, 'Institutional Resilience' (n 5).

${ }^{12}$ Legal culture is understood here as equivalent to the entirety of 'legal practices, i.e. repetitive, socially and culturally pre-definedactions performed by the agents of legal culture (lawyers) within the inter-subjective systems of meanings constituting the interpretive community of lawyers. Therefore legal culture is, on the one hand, the "collective programming of the mind" of the legal community and, on the other hand,the activities (practices) of the members of that community that are informed by such programming' (Rafał Mańko, 'The Unification of Private Law in Europe from the Perspective of Polish Legal Culture' (2007-2008) 11 Yearbook of Polish Legal Studies 109, 112-113, with further references). In this sense, legal culture is distinct from the law (set of rules) and from legal traditions which can inform a given legal culture. Furthermore, legal cultures, in this sense, are usually national law (coincide with nation-states), although supranational legal cultures of international organisations can also emerge (Rafał Mańko and Olga Lachacz, 'Multilingualism at the Court of Justice of the European Union: Theoretical and Practical Aspects' (2013) 34 Studies in Logic, Grammar and Rhetoric 75, 84 , with further references).
} 


\section{STRUCTURE OF THE LAW}

The first dimension of the continuity (or discontinuity) of law, perhaps on the highest level of abstraction, is its structure, understood as the way of ordering of legal material, and as such belonging to the domain of legal aesthetics. ${ }^{13}$ Indeed, any developed legal system is characterised by a certain internal structure which strives at giving the normative material a greater or lesser degree of coherence as part of a systemic approach to the legal order. This structuring can be done both in the legislative texts themselves, as well as by scholars and judges. In particular, legislative structuring of the law is typical for codified legal systems, where the legislation is divided into main 'codes', and the codes themselves are systematically divided into books, titles, chapters, sections and individual articles and sections. On the other hand, in non-codified legal systems (such as Common Law) or de-codified legal systems ${ }^{14}$ (such as EU law), structuring is done more by academics and practitioners. It can either follow from traditional categories (as in the Common Law) or stem from a functionalist paradigm (as in EU law). ${ }^{15}$ The various forms and methods of legal structuring can overlap and compete. The structuring of the law is not a purely theoretical exercise. It has an immense practical impact on the way lawyers think about the law, and on the ways in which it they interpret it. Actually, an important type of legal argument - the 'systemic argument' - is based purely and entirely on a presupposed systemic structure of the law.

The structure of the law is both horizontal and vertical. The horizontal structure divides the law into areas or branches, such as into private and public, or in more detail into the law of obligations, property law, the law of succession, tax law, environmental law and so forth. The vertical structure of the law attempts to differentiate its norms into general principles (of a higher order) and ordinary rules. ${ }^{16}$ The general principles are applicable throughout a given area of the law, or even throughout the entire legal system. The detailed rules do not enjoy such a broad applicability, and their application outside of their ordinary box is referred to as reasoning per analogiam. A special place in the structure of the law is given to constitutional law (in domestic law) and EU law (in the EU) in the sense that all legal norms belonging to those normative bodies are given

\footnotetext{
13 Pierre Schlag, 'The Aesthetics of American Law' (2002) 115.4 Harvard Law Review 1047. Cfr. Jerzy Zajadło, 'Estetyka - zapomniany piąty człon filozofii prawa' (2016) 78.4 Ruch Prawniczy, Ekonomiczny i Socjologiczny 17.

${ }^{14}$ On decodification see e.g. Wojciech Dajczak and Franciszek Longchamps de Bérier, 'Prawo rzymskie w czasach dekodyfikacji' (2012) 10 Forum Prawnicze 8.

15 cf Constanze Semmelmann, 'Theoretical reflections on the public-private distinction and their traces in European Union Law' (2012) 2.4 Oñati Socio Legal Series 25; Constanze Semmelmann, 'The Public-Private Divide in European Union Law or an Overkill of Functionalism' (2012) Maastricht Faculty of Law Working Paper no. 12.

16 The division of legal norms into 'rules' and 'principles' is broadly accepted in contemporary legal theory. See, e.g. Robert Alexy, A Theory of Constitutional Rights (OUP 2010), Ronald Dworkin, Taking Rights Seriously (Harvard UP 1978).
} 
prevalence over 'ordinary legislation' and 'national legislation', respectively.

Continuity or discontinuity of legal culture can be viewed on the level of law's internal structure, for instance the private vs. public division, the opposition between civil law and labour law or civil law and family law. The continued existence of separate labour courts and family courts, as well as a separate Labour Code and Family Code - both enacted under state socialsim - can be regarded as symptoms of the continuity of the Polish legal culture after 1989. Nevertheless it must be kept in mind that similar developments have also been taking place in certain Western European countries, for instance Germany has a separate system of courts deciding labour cases, and France has a separate labour code (Code de travail). These developments were taking place in parallel in the West and East of Europe but their political and ideological underpinnings have been different.

\section{THE CONCEPTUAL FRAMEWORK}

A second dimension of continuity, likewise fairly abstract, are the fundamental concepts of a legal system (its conceptual framework). Any developed legal system has a set of fundamental concepts, which are the cornerstones of a given legal field. For instance, in modern constitutional law these include notions as 'fundamental rights', 'rule of law' (or Rechtstaat), 'constitutional review'and in modern criminal law the notions of 'crime' and 'fault'; in administrative law - the notions of an 'administrative decision', 'organ' and so forth. In the realm of private law, this fundamental conceptual framework is a field of sharp distinctions between the legal families. Within the Germanic legal family, under the influence of the Pandectist school of the $19^{\text {th }}$ century, those central concepts are quite abstract and include, for instance, the 'declaration of will' (Willenserklärung), the 'subjective right' (subjektives Recht) and the 'legal act' (Rechtsgeschäft). In the Common Law family, in contrast, these notions are not that abstract; nevertheless, they can often be quite technical, and include not only 'contract', 'tort', 'liability', but also 'consideration', 'terms and conditions', 'breach', 'reasonable expectations', 'reliance' and the like. Technical concepts such as 'consideration' say nothing to the continental lawyer, just like the notion of 'defects of a declaration of will' seem abstract to an English lawyer.

A special place within the conceptual framework of a given field of law is occupied by notions known as 'general clauses' (Generalklauseln), such as 'good faith' (bona fides), 'good morals' (boni mores), 'equity' (aequitas) or 'reasonableness'. ${ }^{17}$ General clauses play a special role because in codified legal systems they allow for de facto judicial law-making in the guise of resorting to extra-legal systems of values. ${ }^{18}$

17 On general clauses in European private law see e.g. Stefan Grundmann and Denis Mazeaud (eds), General Clauses and Standards in European Contract Law (Kluwer 2006).

${ }^{18}$ For such a realist approach to general clauses see e.g. Martijn Hesselink 'The Concept of Good Faith' in Arthur Hartkamp et al (eds), Towards a European Civil Code, (4 ${ }^{\text {th }}$ ed., Kluwer 2010) 619ff. 
Before the introduction of state socialism on Polish soil, the conceptual framework of private law remained under the influence of the Germanic and Romanic legal families. The Code of Obligations enacted in 1933 leaned towards the Germanic family, drawing strong inspiration from the German Civil Code (BGB) and the Swiss Civil Code (ZGB), with a certain influence also of the Austrian Civil Code (ABGB) and the French Code civil. The fundamental conceptual framework was mainly a reception of Pandectist concepts, and included such notions as 'legal act' (czynność prawna), 'declaration of will' (oświadczenie woli), 'subjective right' (prawo podmiotowe), 'interest' (interes), as well as a set of general clauses of the Western legal tradition, including 'good faith' (dobra wiara), 'good morals' (dobre obyczaje), 'względy słuszności' (reasons of equity), 'usages of fair dealing' (zwyczaje uczciwego obrotu) and 'good mercantile customs' (dobre obyczaje kupieckie).

State-socialist private law represented only a partial departure from this conceptual toolbox. The technical concepts, such as legal act, declaration of will or subjective right were retained, following the model of Soviet law (which, itself, relied heavily on the Pandektenrecht tradition). ${ }^{19}$ However, general clauses were replaced due to a quasi-magical belief in their ideological function. Hence, good faith, good morals and equity were removed, replaced with communist-sounding general clauses, more or less loosely modelled on Soviet law. ${ }^{20}$ These included above all the 'principles of social life' (zasady wspólżycia społecznego), a reception of the Soviet 'principles of socialist life' (printsipy sotsyalisticheskovo obshchezhitya, invented personally by Lenin) and the 'socio-economic purpose' (przeznaczenie społeczno-gospodarcze) which was a reception of the Soviet general clause of 'social purpose', itself modelled on left-leaning French legal doctrine of the pre-WWI period (inter alia Duguit and Saleilles), but codified for the first time in the Civil Code of Soviet Russian of the nep period.

After 1989, an almost intact continuity of the conceptual framework of Polish private law can be witnessed. The only exception is the selective restoration of some Western general clauses (good morals, equity) which co-exist with the Communist general clauses, and new ones imported from EU law (reasonableness) creating a chaotic 'patchwork' system of general clauses. $^{21}$

\footnotetext{
${ }^{19}$ cf Rodolfo Sacco, 'The Romanist Substratum in the Civil Law of the Socialist Countries' (1988) 14.1 Review of Socialist Law 65.

${ }^{20}$ Rafał Mańko, 'Quality of Legislation Following a Transition from Really Existing Socialism to Capitalism: A Case Study of General Clauses in Polish Private Law' in Janis Rozenfelds (ed), The Quality of Legal Acts and its Importance in Contemporary Legal Space (University of Latvia Press 2012) 540ff.

${ }^{21}$ Mańko (n 8) 549-550.
} 


\section{FUNDAMENTAL PRINCIPLES}

A third basic dimension of possible continuity of legal culture is represented by fundamental or general principles of a legal system. The identification of certain norms within the legal system which are given the status of 'fundamental principles' is a relatively recent development. Today, each branch of the law is characterised by a number of fundamental principles, usually distilled by the academics from the broader normative material. ${ }^{22}$ Sometimes, the general principles are expressly formulated in the Codes, as is the case with the Criminal Code (which contains a special section of 'Principles of criminal responsibility') and in the Code of Administrative Procedure. In the Civil Code, the fundamental principles are not spelt out with such clarity and precision, but academics identify them and produce lists of such principles. ${ }^{23}$ Since they are not identified explicitly by the legislature, the lists vary; nevertheless, there is a great deal of overlap between various approaches.

The practical role of general principles is immense. They are resorted to as guidelines for the interpretation of other rules in the legal system, as well as for gap-filling. ${ }^{24}$ If a given situation is not regulated by an immediately available precise rule, courts will resort to general principles in order to draw an answer to the legal question.

Scholars of private law of the socialist period individualised a number of fundamental principles both of substantive private law (civil law) and of civil procedure. Many of these principles were typical for the socialist period.

Writing in 1968, Aleksander Wolter identified nine fundamental principles of the Civil Code: the principle of unity of civil law; the principle of special protection of social property; the principle of unity of all-national property; the principle of linkage between the relationships connecting units of the socialised economy and the execution of economic plans; the principles of basing exchange between units of the socialised economy upon contracts; the principle of full protection of personal property; the principle of civil-law protection of personality rights; the principle of taking into account the principles of social life and the socio-economic purpose of rights. ${ }^{25}$

After 1989, most of these nine principles became outdated. Contemporary authors proposed different catalogues of fundamental principles of private law. Andrzej Bierć enumerates five: autonomy of will; security of turnover; equality of private subjects; equity; effectiveness. ${ }^{26}$ Elżbieta Skowrońska-Bocian also enumerates five, but slightly different: equality of subjects; autonomy of will; respect for the common feeling of

\footnotetext{
${ }^{22}$ The term 'principle' (or 'fundamental principle') is used here in the 'directival sense ... to denote particularly important (chief) norms of a legal system or branch of law' (Zbigniew Radwański, Zarys części ogólnej prawa cywilnego (PWN 1979) 23).

${ }^{23}$ Marek Safjan in System prawa prywatnego. Tom 1. Prawo cywilne - część ogólna (C.H. Beck 2007) 262-268; Radwański (n 22) 23; Andrzej Bierć, Zarys prawa prywatnego. Część ogólna (LEX 2012) 40.

${ }^{24}$ Safjan (n 23) 263, 270-271.

${ }^{25}$ Aleksander Wolter, Prawo cywilne. Zarys części ogólnej (PWN 1968) 52-56.

${ }^{26}$ Bierć (n 23) 41.
} 
justice; security of turnover; equal protection of property. ${ }^{27}$ Certain continuity can be traced between the principle of respect for the principles of social life (Wolter) and the principles of equity (Bierć) or respect for feeling of justice (Skowrońska-Bocian). Principles relating to typically socialist aspects of the legal system - such as state economic planning, priviliged role of social property - are now only of historical interest.

The same observations apply to civil procedure. Writing in 1966, Władysław Siedlecki enumerated 12 fundamental principles of Polish civil procedure: the principle of objective truth; the principle of protection of social property; the principle of cooperation of litigants; the principle of disposal; the principle of equality of parties; the principle of orality and directness; the principle of publicity; the principle of judicial direction; the principle of concentration of material; the principle of free evaluation of evidence; the principle of two-instance proceedings; the principle of procedural formalism. ${ }^{28}$ Writing in 1983, Witold Broniewicz identified 11 principles: the principle of objective truth; the principle of protection of social property; the principle of contradictory proceedings; the principle of disposal; the principle of equality of the parties; the principle of directness; the principle of contentration of the procedural material; the principle of orality; the principle of publicity; the principle of formality of proceeidings; the principle of procedural initiative of judicial and enforcement bodies. ${ }^{29}$

Writing in 2005, Witold Broniewicz identified 10 principles: the principle of substantive truth; the principle of disposal; the principle of contradictory proceedings; the principle of equality of the parties; the principle of concentration of the procedural material; the principle of orality; the principle of publicity; the principle of formality of proceeidings; the principle of procedural initiative of judicial and enforcement bodies. ${ }^{30}$

After 1989, the fundamental principles of private law changed; some immediately, others gradually. For instance, in 1990 the traditional, liberal principle of freedom of contract, absent from the Civil Code 1964, was officially reintroduced and proclaimed in a separate article, modelled on the Code of Obligations. ${ }^{31}$ The principle of special protection of socialised property was replaced with the principle of equal protection of all forms of property. Within procedural law, the changes were introduced at a much slower pace. ${ }^{32}$ However, civil procedure as it stands now is based on entirely different principles than those which were typical for the Communist period. The principle of an active court has been replaced with the principle of active parties who are in charge of putting forward evidence.

\footnotetext{
${ }^{27}$ Elżbieta Skowrońska-Bocian, Prawo cywilne. Część ogólna. Zarys wykładu (LexisNexis 2005) 34-35.

${ }^{28}$ Władysław Siedlecki, Zarys postępowania cywilnego (PWN 1968) 45-70.

${ }^{29}$ Witold Broniewicz, Postepowanie cywilne w zarysie (PWN 1983) 49-63.

${ }^{30}$ Witold Broniewicz, Postępowanie cywilne w zarysie (LexisNexis 2005) 52-65.

31 Article $353^{1}$ k.c.: 'The contracting parties may shape a legal relationship at their discretion, provided that its content or aim do not infringe its nature, legal provisions or the principles of social life.'

${ }^{32}$ For details see e.g. Mańko (n 12).
} 


\section{LEGAL INSTITUTIONS AND RULES}

The four dimensions of continuity of legal culture outline above namely the place of law in society and its concept; the structure of the law; its general concepts; and its general principles - pertained to the aesthetic dimension of the corpus of juridical texts. They describe and reflect the way those texts are arranged (both internally and within the corpus iuris) and identify their fundamental building blocks (concepts and general principles). In a sense, these three dimensions create the basic structure of the law (metaphorically: its reinforced concrete framework), upon which more detailed institutions and rules can be placed (metaphorically: the bricks, filling the framework of reinforced concrete). Therefore, as fifth dimension of continuity of legal culture one should mention legal institutions and the more specific legal rules of which those institutions are built.

It is commonly accepted that a 'legal institution' is something in between a branch of law and a single legal norm or legal rule (the smallest 'unit' of the law). When defining a 'legal institution', authors often refer also to extra-legal elements, pointing out that a legal institution regulates 'a certain typical social relationship', ${ }^{33}$ or that it relates to 'relationships within a given sphere of social life' ${ }^{34}$. It is also underscored that legal norms which are part of a give legal instiution 'fulfil certain functions' 35 and are 'a functional entirety' ${ }^{36}$. Furthermore, the norms or rules which are part of an institution are described as coherent ${ }^{37}$ and mutually interdependent ${ }^{38}$. In sum, a legal instiution can be described as a coherent set of interconnected legal rules which jointly regulate a given sphere of social life. ${ }^{39}$

The continuity of certain legal institutions in a given legal culture is described as the presence of 'legal survivals'. ${ }^{40}$ In Polish private law after 1989, the following legal institutions endured qua legal survivals: prosecutor's locus standi in civil proceeding $\mathrm{s}^{41}$; the preliminary reference ot the Supreme Court by second-instance courts ${ }^{42}$; the extraordinary revision (in the form of the 'extraordinary' cassation of the Prosecutor General ${ }^{43}$ and the new extraordinary petition, introduced in December $2017^{44}$ ); perpetual

\footnotetext{
${ }^{33}$ Adam Łopatka, Wstęp do prawoznawstwa (PWN 1969) 260.

34 Włodzimierz Gromski, in Andrzej Bator (ed), Wprowadzenie do nauk prawnych. Leksykon tematyczny (Wolters Kluwer 2008) 187.

35 Adam Sulikowski, Wstęp do prawoznawstwa. Krótki kurs (Wałbrzyska Wyższa Szkoła Zarządzania i Przesiębiorczości 2007) 61.

${ }^{36}$ Gromski (n 34) 187.

${ }^{37}$ Sulikowski (n 35) 35.

${ }^{38}$ Zygmunt Ziembiński, Problemy podstawowe prawoznawstwa (PWN 1980) 34.

${ }^{39}$ Mańko, 'Transformacja' (n 6) 14.

40 See e.g. Rafał Mańko, 'Legal Survivals: A Conceptual Tool for Analysing PostTransformation Continuity of Legal Culture' in Janis Rozelfelds (ed), The Effectiveness of Law in Post-modern Society (Latvia University Press 2015).

${ }^{41}$ Mańko, 'Demons' (n 6) 80-84.

42 ibid 84-85.

${ }^{43}$ Rafał Mańko, 'Is the Socialist Legal Tradition "Dead and Buried"? The Continuity of Certain Elements of Socialist Legal Culture in Polish Civil Procedure' in Thomas Wilhemsson (ed), Private Law and the Many Cultures of Europe (Kluwer 2007) 94-99.

${ }^{44}$ Ustawa z dnia 8 grudnia 2017 r. o Sądzie Najwyższym (Dz.U. 2018, item 5), Art. 89ff.
} 
usufruct $^{45}$; cooperative member's proprietary right to an apartment (new rights can no longer be created $)^{46}$; cooperative member's tenancy right to an apartment (which can still be created) ${ }^{47}$ the cultivation contract ${ }^{48}$; the delivery contract. ${ }^{49}$ It follows that the number of legal institutions is perhaps not great (three institutions of civil procedure, two property rights and one quasi-property right; two contractus nominati), nonetheless they occur in all spheres of private law and many of them pertain to the everyday life of citizens, companies and litigants, being a permanent element of contemporary Polish legal landscape.

\section{CONCLUSIONS}

This paper was intended as a merely preliminary enquiry into the possibility of putting forward a set of comparable, high-level notions denoting the aspects (dimensions) of legal continuity sensu stricto, i.e. the continuity of law in the positivist sense (as a set of legal norms in force). This modest ambition removed from the scope of research such aspects of legal culture as the continuity of adjudication (references to earlier case-law, the continuity of methods of judicial reasoning) or the continuity of legal scholarship, as well as the problems of the social functions of law, its branches, its institutions and individual norms. The task of devising a research framework for analysing the continuity of these vast areas of legal culture is yet to be devised.

As regards the dimensions of continuity of law, the paper proposed four such dimensions: the structure of the law, its conceptual framework, its fundamental principles and, finally, its normative building blocks: institutions and individual rules. Differentiating between these four distinct dimensions allows to get a better picture of legal continuity; instead of a two-dimenional one, focused only on the continuity of legal rules (legal provisions), it allows seeing continuity also on higher levels of the positive law: in the law's internal structure, in its fundamental concepts and fundamental principles. Also, looking upon legal provisions as expressing legal norms which are the building blocks of legal institutions helps to avoid the impression of discontinuity in situations where continuity is latent, but by no means absent. This is because legal institutions, such as the

\footnotetext{
45 Rafał Mańko, 'Prawo użytkowania wieczystego jako pozostałość po epoce realnego socjalizmu - ujęcie socjologicznoprawne’ (2017) 17.1 Zeszyty Prawnicze 33.

${ }^{46}$ Rafał Mańko, 'The Cooperative Member's Proprietary Right to an Apartment: A Legal Survival of the Period of Actually Existing Socialism in Polish Private Law' (2015) 15.4 Zeszyty Prawnicze 147.

${ }^{47}$ Ustawa z dnia 15 grudnia 2000 r. o spółdzielniach mieszkaniowych (Dz.U. No 4, item 27, as amended), Art. 9ff. The tenancy right to an apartment in a housing cooperative qua legal survival still requires in-depth socio-legal research.

${ }^{48}$ Rafał Mańko, 'Wybrane relikty prawne epoki socjalizmu realnego w polskim prawie cywilnym - analiza zmiany funkcji społecznej instytucji prawnych w następstwie transformacji ustrojowej' (2016) 76 Studia Iuridica 207, 229-230.

${ }^{49}$ Art. 605ff of the Polish Civil Code. The delivery contract (umowa dostawy) qua survival of the Socialist Legal Tradition still requires to be studied in more detail.
} 
extraordinary revision (in its successor forms of extraordinary cassation and the recently introduced extraordinary petition) or the tenancy right to an apartment in a cooperative may be expressed in different legal provisions (in new acts), may even contain new (different) legal norms, but nonetheless remain the same legal institutions, i.e. they maintain their identity. ${ }^{50}$

\section{Bibliography}

Alexy R, A Theory of Constitutional Rights (OUP 2010). Kluwer 2008)

Bator A, (ed), Wprowadzenie do nauk prawnych. Leksykon tematyczny (Wolters

Bierć A, Zarys prawa prywatnego. Część ogólna (LEX 2012).

Borisova T, 'The Institutional Resilience of Russian Law Through 1905-1917' (2017) 5.4 Russian Law Journal 108.

Borisova T, 'The Legitimacy of the Bolshevik Order, 1917-1918: Language Usage in Revolutionary Russian Law' (2012) 37.4 Review of Central and East European Law 395.

Borisova T, Siro J, 'Law between Revolution and Tradition: Russian and Finnish Revolutionary Legal Acts, 1917-1918’ (2014) 3 Comparative Legal History 84.

Broniewicz W, Postępowanie cywilne $w$ zarysie (LexisNexis 2005).

Broniewicz W, Postepowanie cywilne w zarysie (PWN 1983).

Dajczak W, Longchamps de Berier F, 'Prawo rzymskie w czasach dekodyfikacji' (2012) 10 Forum Prawnicze 8.

Dworkin R. Taking Rights Seriously (Harvard UP 1978).

Giaro, T. 'Some Prejudices about the Legal Tradition of Eastern Europe' in Bronisław Sitek (ed), Comparative Law in Eastern and Central Europe (Cambridge Scholars Publishing 2013).

Grundmann S, Mazeaud D (eds), General Clauses and Standards in European Contract Law (Kluwer 2006).

Hesselink MW, 'The Concept of Good Faith' in Arthur Hartkamp et al (eds), Towards a European Civil Code (4 ${ }^{\text {th }}$ ed., Kluwer 2010).

Kelemen K, Fekete B, 'How Should the Legal Systems of Eastern Europe Be Classified Today?' in Attila Badó et al (eds), International Conference for the 10th Anniversary of the Institute of Comparative Law of the University of Szeged (Universitätsverlag Potsdam 2014)

Kelemen K, 'I sistemi giuridici dell'Europa orientale' in Vittoria Barsotti \& Vincenzo Varano (eds), La tradizione giuridica occidentale: Testo e materiali per un confronto civil law common law (5th ed. Giapichelli 2014).

Kojève A, Outline of a Phenomenology of Right [1943] (Rowman and Littlefield

Kühn Z, The Judiciary in Central and Eastern Europe: Mechanical Jurisprudence in Transformation? (Martinus Nijhoff 2011).

Łopatka A, Wstęp do prawoznawstwa (PWN 1969).

Mańko R, 'Demons of the Past? Legal Survivals of the Socialist Legal Tradition in Contemporary Polish Private Law' in Rafał Mańko, Cosmin Cercel and Adam Sulikowski (eds), Law and Critique in Central Europe: Questioning the Past, Resisting the Present (Counterpress 2016).

Mańko R, 'Is the Socialist Legal Tradition "Dead and Buried"? The Continuity of Certain Elements of Socialist Legal Culture in Polish Civil Procedure' in Thomas Wilhemsson (ed), Private Law and the Many Cultures of Europe (Kluwer 2007) 94-99.

Mańko R, 'Legal Survivals: A Conceptual Tool for Analysing PostTransformation Continuity of Legal Culture' in Janis Rozelfelds (ed), The Effectiveness of Law in Post-modern Society (Latvia University Press 2015).

Mańko R, 'Prawo użytkowania wieczystego jako pozostałość po epoce realnego socjalizmu - ujęcie socjologicznoprawne’ (2017) 17.1 Zeszyty Prawnicze 33.

\footnotetext{
${ }^{50}$ cf Mańko, 'Transformacja' (n 6) 18-21.
} 
Mańko R, 'The Unification of Private Law in Europe from the Perspective of Polish Legal Culture' (2007-2008) 11 Yearbook of Polish Legal Studies 109.

Mańko R, 'Transformacja ustrojowa a ciągłość instytucji prawnych - uwagi teoretyczne' (2016) 16.2 Zeszyty Prawnicze 5.

Mańko R, 'Wybrane relikty prawne epoki socjalizmu realnego w polskim prawie cywilnym - analiza zmiany funkcji społecznej instytucji prawnych w następstwie transformacji ustrojowej' (2016) 76 Studia Iuridica 207.

Mańko R, Łachacz O, 'Multilingualism at the Court of Justice of the European Union: Theoretical and Practical Aspects' (2013) 34 Studies in Logic, Grammar and Rhetoric 75.

Mańko R, Škop M, Štěpáníková M, 'Carving out Central Europe as a Space of Legal Culture: A Way Out of Peripherality?' (2016) 6.2 Wroclaw Review of Law, Administration and Economics.

Mańko R,'The Cooperative Member's Proprietary Right to an Apartment: A Legal Survival of the Period of Actually Existing Socialism in Polish Private Law' (2015) 15.4 Zeszyty Prawnicze 147.

Mańko R, 'Quality of Legislation Following a Transition from Really Existing Socialism to Capitalism: A Case Study of General Clauses in Polish Private Law' in Janis Rozenfelds (ed), The Quality of Legal Acts and its Importance in Contemporary Legal Space (University of Latvia Press 2012) 540ff.

Nazmutdinov BV, [Назмутдинов Б.В.], Законь из-за гранищь: Политикоправовые аспекты классического евразийства (Норма 2017).

Radwański Z, Zarys części ogólnej prawa cywilnego (PWN 1979).

Sacco R, 'The Romanist Substratum in the Civil Law of the Socialist Countries' (1988) 14.1 Review of Socialist Law 65.

Safjan M, in System prawa prywatnego. Tom 1. Prawo cywilne - czesść ogólna (C.H. Beck 2007).

Schlag P, 'The Aesthetics of American Law' (2002) 115.4 Harvard Law Review 1047.

Semmelmann C, 'Theoretical reflections on the public-private distinction and their traces in European Union Law' (2012) 2.4 Oñati Socio Legal Series 25.

Semmelmann C, 'The Public-Private Divide in European Union Law or an Overkill of Functionalism' (2012) Maastricht Faculty of Law Working Paper no. 12.

Siedlecki W, Zarys postępowania cywilnego (PWN 1968). 2005).

Skowrońska-Bocian E, Prawo cywilne. Część ogólna. Zarys wykładu (LexisNexis

Sulikowski A, Wstęp do prawoznawstwa. Krótki kurs (Wałbrzyska Wyższa Szkoła Zarządzania i Przesiębiorczości 2007). Review 377.

Uzelac A, 'Survival of the Third Legal Tradition?' (2010) 49 Supreme Court Law

Wolter A, Prawo cywilne. Zarys części ogólnej (PWN 1968).

Woodruff D, 'Phenomenology' in Edward N Zalta (ed) The Stanford Encyclopedia of Philosophy (Winter 2016 Edition), available online at: https://plato.stanford.edu/archives/win2016/entries/phenomenology/, accessed 21 January 2018.

Zajadło J, 'Estetyka - zapomniany piąty człon filozofii prawa' (2016) 78.4 Ruch Prawniczy, Ekonomiczny i Socjologiczny 17.

Ziembiński Z, Problemy podstawowe prawoznawstwa (PWN 1980). 